\title{
Ranavirus in wild edible frogs Pelophylax kl. esculentus in Denmark
}

\author{
Ellen Ariel ${ }^{1,7, *}$, Jos Kielgast ${ }^{2}$, Hans Erik Svart ${ }^{3}$, Knud Larsen $^{4}$, Hannele Tapiovaara ${ }^{5}$, \\ Britt Bang Jensen $^{1,6}$, Riikka Holopainen ${ }^{5}$
}

\author{
${ }^{1}$ National Veterinary Institute, Technical University of Denmark, Hangøvej 2, 8200 Århus N, Denmark \\ ${ }^{2}$ Department of Biology, Section for Microbiology and Evolution, University of Copenhagen, Universitetsparken 15 , \\ 2100 Copenhagen, Denmark \\ ${ }^{3}$ Danish Forest and Nature Agency, Haraldsgade 53, 2100 Copenhagen Ø, Denmark \\ ${ }^{4}$ Council of Slagelse, Dahlsvej 3, Korsør 4220, Denmark \\ ${ }^{5}$ Department of Veterinary Virology, Finnish Food Safety Authority Evira, Mustialankatu 3, Helsinki, Finland \\ ${ }^{6}$ Department of Large Animal Sciences, Faculty of Life Sciences, University of Copenhagen, Grønnegårdsvej 8, \\ 1870 Frederiksberg C, Denmark \\ ${ }^{7}$ Present address: School of Veterinary and Biomedical Sciences, James Cook University, Douglas Campus, \\ Townsville, Queensland 4811, Australia
}

\begin{abstract}
A survey for the amphibian pathogens ranavirus and Batrachochytrium dendrobatidis $(B d)$ was conducted in Denmark during August and September 2008. The public was encouraged via the media to register unusual mortalities in a web-based survey. All members of the public that registered cases were interviewed by phone and 10 cases were examined on suspicion of diseaseinduced mortality. All samples were negative for $B d$. Ranavirus was isolated from 2 samples of recently dead frogs collected during a mass mortality event in an artificial pond near Slagelse, Denmark. The identity of the virus was confirmed by immunofluorescent antibody test. Sequencing of the major capsid protein gene showed the isolate had more than $97.3 \%$ nucleotide homology to 6 other ranaviruses.
\end{abstract}

KEY WORDS: Ranavirus - Batrachochytrium dendrobatidis $\cdot$ Rana kl. esculenta Pelophylax kl. esculentus $\cdot$ Amphibian declines $\cdot$ Survey $\cdot$ Frogs $\cdot$ Amphibians

\section{INTRODUCTION}

The recent listing of Batrachochytrium dendrobatidis $(B d)$ and ranavirus infection in amphibians by the World Organisation for Animal Health (OIE) reflects a global concern for the health of farmed and declines of wild populations of amphibians (OIE 2008). Reports on ranavirus disease in amphibians are listed in the literature (Speare \& Smith 1992, Kanchanakhan et al. 2002 Zupanovic et al. 1998, Zhang et al. 2001, Green et al. 2002, Weng et al. 2002, Greer et al. 2005, Fox et al. 2006) and several publications indicate that rana- viruses are part of the cause of amphibian declines across the world (Cunningham et al. 1996, Chinchar 2002, Green et al. 2002, Docherty et al. 2003, Pearman et al. 2004, Greer et al. 2005, Jancovich et al. 2005).

The type species of the ranavirus genus, frog virus 3 (FV3), was isolated for the first time in 1965 (Granoff et al. 1965, Rafferty 1965). In Europe, ranaviruses were isolated from moribund edible frogs Pelophylax kl. esculentus (formerly Rana kl. esculenta) in Croatia (Fijan et al. 1991) and Italy (G. Bovo pers. comm.) and from wild populations of the common frog Rana temporaria in the UK (Drury et al. 1995). The origin of these 
viruse is unknown, as is the influence of ranaviral disease on the wild populations of amphibians in Europe. As part of the project Risk Assessment of New and Emerging Systemic Iridoviral Diseases for European Fish and Aquatic Ecosystems (RANA), a survey was conducted in several European countries to gain knowledge of the current presence of ranaviruses in wild amphibian populations. In Denmark, the public was engaged in the survey to broaden the chances of identifying and registering unusual amphibian mortalities in the wild populations. The results of the Danish survey are reported here.

\section{MATERIALS AND METHODS}

Survey of amphibian mortality. The purpose of the survey was to identify amphibians that had died due to an infectious disease and the questionnaire was therefore designed to filter out other causes. The questionnaire covered the contact details of the reporting person, the location and date of the observed amphibian(s), the perceived cause of death, type of amphibian, number of dead and/or affected animals and details of previous similar incidences. The questionnaire could be accessed via the RANA project's website and was active during August and September 2008. A statement was released to the media in early August 2008 to draw public attention to the survey. If a case of mortality was registered as potentially induced by infectious disease, the responder to the survey was instructed to freeze the dead amphibian until contacted by a scientist. The scientist conducted a secondary screening via a telephone interview to determine which cases should be submitted to the National Veterinary Institute of Denmark for further investigation under permit no. SNS-44100104. Follow-up investigation on the positive cases was carried out as collaboration between the National Veterinary Institute, the Council of Slagelse and the Danish Forest and Nature Agency. Extensive testing for environmental pollutants in the water was carried out (Højvang Environmental Laboratory, 4293 Dianalund, Denmark) and weather patterns were consulted for the period of the outbreak in the archives of the Danish Meteorological Institute (www.dmi.dk).

Laboratory examination. Thawed amphibian specimens were examined for gross lesions. Prior to dissection, diagnostic skin swabs for $B d$ were taken using fine tip dry-swabs (MW100, Medical Wire and Equipment) according to the standard protocol by Hyatt et al. (2007). Spleen, liver, lung, kidney and heart tissues were pooled for each animal and examined according to standard virological techniques for fish tissues (Anonymous 2001) in epithelioma papulosum cyprini
(EPC) cells (Fijan et al. 1983) at $21^{\circ} \mathrm{C}$. Titrations were carried out as 6 well replicates in 96 well plates with 10 -fold dilutions of the viral inoculum on EPC cells at $21^{\circ} \mathrm{C}$. The progress of cytopathic effect (CPE) was observed by light microscope and recorded at regular intervals with the final reading $7 \mathrm{~d}$ after inoculation. The titre was calculated as $\mathrm{TCID}_{50} \mathrm{ml}^{-1}$ according to the Reed \& Muench (1938) method for end-point titrations.

PCR for Bd. The diagnostic swabs were stored at $-20^{\circ} \mathrm{C}$ until processed. DNA was extracted and analysed via realtime PCR following Boyle et al. (2004) with minor modifications. The tip of each swap was cut off into a screw top Eppendorf tube with $60 \mu \mathrm{l}$ of PrepMan Ultra (Applied Biosystems) and 30 to $40 \mathrm{mg}$ of zirconium/silica beads (0.5 mm diameter, Biospec Products) added. The samples were homogenised for $45 \mathrm{~s}$ and subsequently centrifuged $(30 \mathrm{~s}$ at $13000 \times g$ in a microfuge) to pellet the material. Homogenisation and centrifugation was repeated. The homogenised sample was placed in a heating block at $100^{\circ} \mathrm{C}$ for $10 \mathrm{~min}$, cooled for $2 \mathrm{~min}$ and then centrifuged at $13000 \times \mathrm{g}$ for $3 \mathrm{~min}$ in a microfuge. The supernatant was recovered and a subsample of this DNA extract diluted $10^{-1}$ in water for further analysis.

DNA samples were analysed by real-time PCR using primers ITS-1 Chytr and 5.8S Chytr with a minor groove binder probe ChytrMGB2 (GenBank accession no. AY598034). The specificity of the assay has been confirmed against 26 other Chytridiomycetes (Boyle et al. 2004). All samples and amplification standards of $0.1,1,10$ and 100 genome equivalents were run in duplicate together with a positive extraction, a negative extraction and a no template control (distilled water). Twenty $\mu \mathrm{l}$ of TaqMan mastermix/primers/ probe/distilled water and $5 \mu \mathrm{l}$ of sample, standard or control was pipetted into each well. The plate was then centrifuged at $2750 \times g$ for 3 min and samples were screened using default amplification settings on an ABI prism 7700. Samples were identified as positive for $B d$ if a clear log-linear amplification was observed for both replicates and genomic equivalents quantified according to the standards.

Immunofluorescent antibody test. Supernatant from samples inducing CPE in the cell cultures were inoculated onto EPC cells in 96 well plates and incubated for $24 \mathrm{~h}$ at $24^{\circ} \mathrm{C}$, using negative cell culture supernatant as negative control and epizootic hematopoietic necrosis virus (EHNV; kindly supplied by R. Whittington, University of Sydney, Australia) as positive control. They were then rinsed and fixed in $80 \%$ acetone prior to staining for immunofluorescence as described by Jørgensen et al. (1989). Briefly, primary antibodies (polyclonal rabbit sera) produced against European catfish virus (ECV) (Bovo et al. 1993; kindly provided by G. 
Bovo, Instituto Zooprofilattico Sperimentale delle Venezie, Italy) was diluted 1:800 in phosphate buffered saline (PBS) without $\mathrm{Ca}^{2+}$ and $\mathrm{Mg}^{2+}$ and used as the primary antibody. This antibody cross-reacts with other ranavirus isolates and is specific to ranaviruses (G. Bovo pers. comm.). The plates were then incubated for $30 \mathrm{~min}$ at $37^{\circ} \mathrm{C}$. Rhodamineconjugated swine-anti-rabbit IgG (F0205, Dako) was applied as secondary antisera in a dilution of 1:100 in PBS for $30 \mathrm{~min}$ at $37^{\circ} \mathrm{C}$. The samples were examined for immunofluorescent staining by fluorescence microscope.

PCR, DNA sequencing and DNA sequence analysis for ranavirus. The viral DNA was extracted from the infected EPC cells by a QiaAmp DNA Mini Kit (Qiagen) according to the manufacturer's protocol. The complete major capsid protein (MCP; $1392 \mathrm{bp}$ ) gene of the 2 Pelophylax esculentus viral isolates, case nos. 2008-50-283-1 and -2 (PEV-DK1 and PEV-DK2), was amplified using PCR primers and conditions published by Hyatt et al. (2000, modified from their Table 4) (Table 1). The PCR products were sequenced using a Big Dye Terminator v1.1 Cycle Sequencing Kit (Applied Biosystems) and an ABI PRISM 3100-Avant Genetic Analyzer (Applied Biosystems). The sequence data was analyzed with Sequencing Analysis Software 5.1 (Applied Biosystems) and multiple sequence alignments were done with CLUSTAL_X 1.81 (Thompson et al. 1997). The values for sequence pair percent identity were calculated by the MegAlign program from the Lasergene 7.1 application package (DNASTAR).

\section{RESULTS}

The press release created a good deal of interest with the media in Denmark: 11 websites (4 news sites, 6 environmental associations), 2 newspapers and 2 radio stations published the story. The web survey returned 25 cases which were potentially induced by infectious disease. After telephone interviews, 13 cases were submitted, out of which 10 were of a suitable con- dition for testing ( 7 Bufo bufo, 2 Rana temporaria and 1 Pelophylax esculentus). Most of these were single frog incidences, but in 2 cases mass mortality was reported: $B$. bufo near Ebeltoft and $P$. esculentus from a pond near Slagelse, Denmark. The $B$. bufo mass mortality appeared to be caused by extreme arid conditions. Two individual samples (case nos. 2008-50-282-1 and -2) from the $P$. esculentus mass mortality near Slagelse tested positive for ranavirus. The landowner reported approximately 1200 dead frogs over the course of the weekend of 3-4 August 2008. For 2 wk prior to this he had occasionally noticed dead frogs in the area, but the bulk of the population in the pond perished over those few days and hardly any were left after the main dieoff. The frogs were found dead in resting position along the edge of a shallow (1 $\mathrm{m}$ deep) artificial pond. No clinical signs were observed. The pond was dug out 9 yr previously and situated in the middle of a grazing field with very little vegetation along the edge, no agricultural activity nearby and no water flowing through it. The invertebrate fauna (including introduced Astacus astacus) and the fish in the lake (Cyprinus carpio) appeared healthy and were not investigated. The air temperatures leading up to and during the period of the outbreak were unusually high and the weather was described as a heat wave for Danish climate conditions: the maximum air temperature for that week was registered as $30.7^{\circ} \mathrm{C}$ for the area (www.dmi.dk).

All samples in the 10 cases were negative for $B d$. Samples from 2 wild Pelophylax esculentus from the same location near Slagelse (case nos. 2008-50-283-1 and -2) produced CPE in cell culture. The titers of virus in the organs were $7 \times 10^{4}$ and $2.3 \times 10^{7} \mathrm{TCID}_{50} \mathrm{ml}^{-1}$ for the 2 samples, respectively. Cultures infected with these isolates stained positive for ranavirus using the immunofluorescent antibody technique. Pelophylax esculentus viral isolates (PEV-DK1 and PEV-DK2) were $100 \%$ identical and showed more than $97.3 \%$ nucleotide similarity when compared to the previously published MCP gene sequences of other ranaviruses: frog virus 3 (FV3), AY548484; Bohle iridovirus (BIV), AY187046; epizootic hematopoietic necrosis virus

Table 1. PCR primers for amplifying the major capsid protein (MCP) gene of ranaviruses (Hyatt et al. 2000 adapted from their Table 4, with permission). Primer position is relative to the initiator nucleotide of the epizootic hematopoietic necrosis virus MCP gene

\begin{tabular}{|lcl|}
\hline Primer designation & Primer position & Nucleotide sequence (5' to $\left.3^{\prime}\right)$ \\
\hline MCP-1 & -27 to +3 & CAC CGT GTA TCT TAT AAT AAA AAG GAA ATG \\
MCP-2R & 516 to 498 & GGC TCC GTC CTG GCC TGT G \\
MCP-3 & 443 to 468 & GAG GCC AAG CGC ACA GGC TAC \\
MCP-4R & 959 to 940 & TTG GAG CCG ACG GAA GGG TG \\
MCP-5 & 900 to 920 & CGC AGT CAA GGC CTT GAT GT \\
MCP-6R & 1484 to 1463 & AAA GAC CCG TTT TGC AGC AAA C \\
\hline
\end{tabular}


(EHNV), AY187045; Ambystoma tigrinum virus (ATV), NC_ 005832; tiger frog virus (TFV), AF389451; and Rana esculenta virus (REV), REV 282/I02 (Holopainen et al. 2009) (Table 2).

The amino acid sequence alignment of PEV-DK1 and PEV-DK2 MCP genes with other ranaviruses is presented in Fig. 1. The MCP gene sequence of PEVDK1 was submitted to GenBank with accession no. FJ515796. Laboratory tests (Højvang Environmental Laboratory) for environmental pollutants in the water (pesticides, solvents, phenols and components of oil and sulphur) were all negative.

\section{DISCUSSION}

Amphibians are cryptic by nature and individuals dying of natural causes are rarely noticed before they are scavenged or decompose. Creating and utilising public awareness in surveys can increase the chances of detecting disease-induced mortality in cryptic taxa like amphibians. Our survey led to the discovery of one of the most severe ranavirus-associated mass die-offs observed in a free-living amphibian population. Only one case of those reported in the survey was positive for ranavirus and none for $B d$. With all the public attention and only one case of ranavirus detected, it is likely that outbreaks caused by ranavirus or chytrid fungus of this proportion were unusual in Denmark during this period.

Frog farming is a rarity in northern Europe, and ranavirus infection in amphibians would therefore not have any commercial impact. However, the effect of ranavirus on wild populations of amphibians is potentially devastating. All amphibians are protected under statutory order in Denmark due to the general threat of extinction (Anonymous 2007). If the virus spreads in wild populations of amphibians it may have severe consequences on the infected populations of amphibians, other susceptible species and their predators.
Denmark is on the northern border of the range of Pelophylax esculentus, and populations are fragmented and have decreased over the last decades (Fog et al. 1997). These circumstances make this species particularly vulnerable to disease.

Interviews with the landowner at the site near Slagelse where the Pelophylax esculentus mortality was detected did not cast light on a possible pathway of introduction of this virus into the pond. However, ranaviruses are causing disease outbreaks in frogs on all continents except for Africa and Antarctica (Williams et al. 2005); therefore, the presence of ranavirus in the environment is not an unusual observation (Green et al. 2002). Further epidemiological studies may cast light on the origin of this isolate.

A very high density of frogs was observed in and near the aforementioned pond over the summer. In the weeks prior to the outbreak the weather was unusually warm and the temperature of the water in the pond would have reflected this. There was no shade around or near the pond for the frogs to shelter. These exceptional environmental conditions could affect the immunological response of the frogs and induce conditions for rapid spread and high pathogenicity of the virus (Jancovich et al. 1997, Carey et al. 1999, Brunner et al. 2005). Water analysis did not reveal any known pollutants and both frogs submitted from the site were negative for $B d$ and positive for ranavirus with high titres in the organs. Based on previous reports concerning the epidemiology of ranavirus disease in amphibians (Jancovich et al. 1997, Green et al. 2002, Pearman et al. 2004, Rojas et al. 2005), it is highly likely that the infection caused or contributed to the deaths of the frogs in this population. Challenge studies of frogs with this isolate would further clarify its role in the epizootic, especially by enabling pathological investigation of fresh specimens.

Repetitive isolations of ranavirus from moribund edible frogs (11 positive out of 16 samples over an $11 \mathrm{yr}$ period) collected from the wild and kept for commer-

Table 2. Nucleotide sequence similarity (\%) of complete major capsid protein gene (1392 bp) of Danish Pelophylax esculentus viral isolates (PEV-DK-2008-50-283-1 and -2) compared to other ranaviruses. REV 282/I02: Rana esculenta virus 282/I02; FV3: frog virus 3; BIV: Bohle iridovirus; EHNV: epizootic hematopoietic necrosis virus; ATV: Ambystoma tigrinum virus; TFV: tiger frog virus

\begin{tabular}{|llll}
\hline Isolate & Nucleotide sequence similarity (\%) & Host species & GenBank accession nos. \\
\hline PEV-DK1 & 100 & Pelophylax esculentus & FJ515796 \\
PEV-DK2 & 100 & Pelophylax esculentus & FJ515796 \\
REV 282/I02 & 99.6 & Pelophylax esculentus & Holopainen et al. (2009) \\
FV3 & 98.3 & Rana pipiens & AY548484 \\
BIV & 98.4 & Limnodynates ornatus & AY187046 \\
EHNV & 98.8 & Pelophylax fluviatilis & AY187045 \\
ATV & 97.3 & Ambystoma tigrinum & NC_005832 \\
TFV & 98.4 & Rana tigrina & AF389451 \\
\hline
\end{tabular}




$\begin{array}{ll}\text { FV3 } & : \\ \text { BIV } & : \\ \text { EHNV } & : \\ \text { ATV } & : \\ \text { TFV } & : \\ \text { PEV_DK1 } & : \\ \text { PEV_DK2 } & :\end{array}$

80

FV3

BIV

EHNV

ATV

TFV

PEV DK1 PEV_DK2

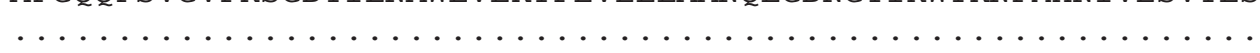

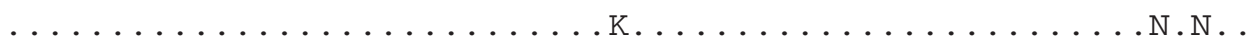

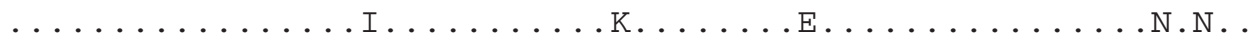

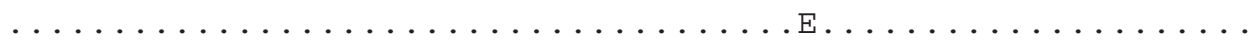

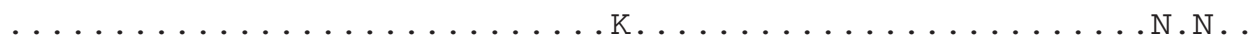

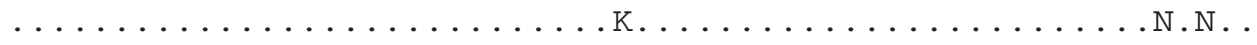

260

280

TFV

FV3
BIV
EHNV
ATV
TFV
PEV_DK1
PEV_DK2

Fig. 1. Amino acid sequence alignment of the major capsid protein gene of several ranaviruses. Previously published sequences: frog virus 3 (FV3; AY548484), Bohle iridovirus (BIV; AY187046), epizootic hematopoietic necrosis virus (EHNV; AY187045), Ambystoma tigrinum virus (ATV; NC_005832) and tiger frog virus (TFV; AF389451). Identical amino acids are marked with a dot, STOP-codons are marked with an asterisk 


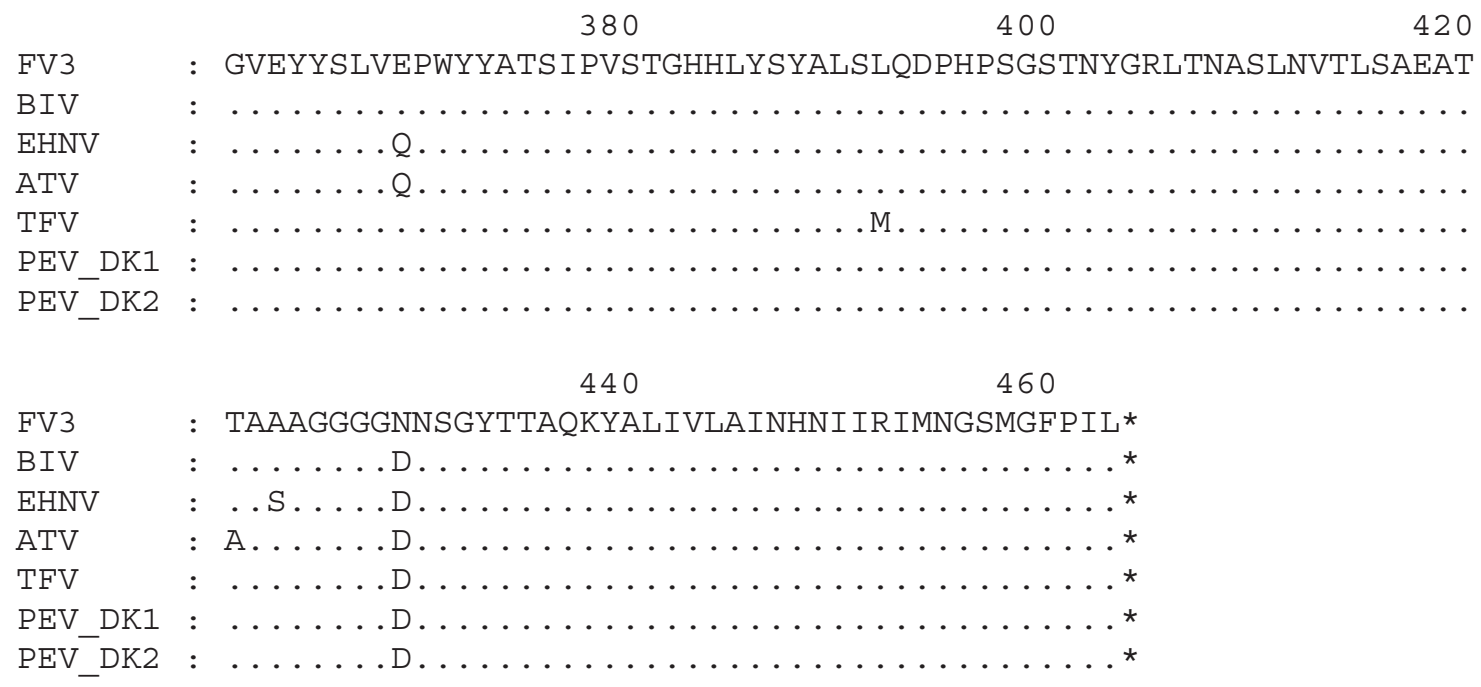

Fig. 1. (continued)

cial purposes in Croatia spurred investigations into the virulence of the isolates to healthy edible frogs (Fijan et al. 1991). Experimental challenge via various routes did not produce disease in the frogs over $30 \mathrm{~d}$, although low titres of virus were present in frogs from all treatments apart from the negative control. This questions the role of ranavirus as a primary pathogen in edible frogs. It may be an opportunistic pathogen which coexists at low levels within the host except when the host is weakened and the environmental conditions are conducive to viral replication. Under such conditions the virus may turn pathogenic and cause disease in the host as reported here.

The MCP gene is commonly used in defining taxonomy in the virus family Iridoviridae (Chinchar 2002) and in differentiating ranavirus isolates (Mao et al. 1999, Hyatt et al. 2000, Marsh et al. 2002, Do et al. 2005). The MCP sequences of PEV-DK1 and PEV-DK2 were identical to each other. Our sequence comparison included 3 ranaviruses isolated in amphibian disease outbreaks: BIV (Speare \& Smith 1992), ATV (Jancovich et al. 1997), TFV (Kanchanakhan et al. 2002) and EHNV from disease outbreaks in perch in Australia (Langdon et al. 1986). Based on sequence comparison of the complete MCP gene, BIV, ATV, TFV, EHNV, REV 282/I02 and FV3 were very closely related (97.3 to $99.6 \%$ nucleotide identity) to the Danish frog virus isolates (Table 2). The comparison of the MCP sequences indicates that PEV-DK belongs to the genus Ranavirus. These results are in accordance with species demarcation criteria in the genus Ranavirus (Chinchar et al. 2005). The closest relative to Danish frog isolates was PEV 282/I02, which was also isolated from an edible frog, with nucleotide identity of $99.6 \%$ and amino acid identity of $100 \%$ (results not shown). Surprisingly, in the present study, the second closest relative to the Danish frog isolates was EHNV isolated from fish on another continent, with nucleotide identity of $98.8 \%$. At the protein level there were 5 amino acid changes between EHNV and PEV-DK (Fig. 1).

Despite the severity of amphibian declines due to infectious diseases, it is difficult to envisage how control and containment of ranavirus in wild frogs can be achieved (Mendelson et al. 2006, Gascon et al. 2007). The nature of wild animals makes it very difficult to ensure non-destructive containment of animals in an infected area. When frogs migrate from a pond in the autumn they may be in contact with other frog populations and contaminate them. Viruses could also spread by vectors such as birds, fish or downstream via the water.

The risk of ranavirus outbreaks is not limited to amphibians. Evidence for transmission of ranavirus between frogs and fish has been recorded (Moody \& Owens 1994, Ariel \& Owens 1997, Mao et al. 1999) and one host species may act as reservoir for the other (Mao et al. 1999, Duffus et al. 2008). EHNV, ECV and European sheatfish virus (ESV) are listed by the OIE for fish and they are closely related to this new strain. All the listed viruses were involved in natural outbreaks in wild populations of perch, catfish and sheatfish (Langdon et al. 1986, Ahne et al. 1989, Bovo et al. 1993, Bigarré et al. 2008) and several other species of fish and frogs are experimentally susceptible to ranavirus infection (Langdon 1989, Moody \& Owens 1994, Ariel \& Owens 1997, Cullen \& Owens 2002, Bang Jensen et al. 2009). Potentially, this new Pelophylax esculentus viral isolate could therefore pose a risk to both amphibian and piscine fauna. To balance these apocalyptic statements there are also many reports of ranavirus isolations from animals with no clinical 
symptoms, where the virus apparently is not causing the host any distress (Jensen et al. 1979, Tapiovaara et al. 1998, Harp \& Petranka 2006, Duffus et al. 2008).

This is the first survey for viruses in Danish frogs and the first record of ranavirus in Danish amphibians. Although ranavirus could occur naturally as part of the ecosystem, the finding of high titres of ranavirus associated with mass mortalities in frogs demonstrates the possible consequences of infection given the right environmental circumstances.

Acknowledgements. We thank the RANA consortium for commenting on the questionnaire format. N. Nicolajsen, J. Mølgaard, M. B. Christophersen and U. Tobler are acknowledged for their technical assistance. This research was carried out under the RANA project under the Sixth Framework Programme funded by the European Commission.

\section{LITERATURE CITED}

Ahne W, Schlotfeldt HJ, Thomsen I (1989) Fish viruses: isolation of an icosahedral cytoplasmic deoxyribovirus from sheatfish (Siluris glanis). J Vet Med Ser B 36:333-336

Anonymous (2001) Commission Decision of 22 February 2001 laying down the sampling plans and diagnostic methods for the detection and confirmation of certain fish diseases and repealing Decision 92/532/EEC. Off J Eur Union 31:436-442

Anonymous (2007) Bekendtgørelse om fredning af visse dyre- og plantearter mv., indfangning af og handel med vildt og pleje af tilskadekomment vildt; Bekendtgørelse nr. 901 af 11. juli 2007 (Statutory order no. 901, July 2007). Danish Ministry of the Environment, Copenhagen

> Ariel E, Owens L (1997) Epizootic mortalities in tilapia Oreochromis mossambicus. Dis Aquat Org 29:1-6

Bang Jensen B, Kjær Ersbøll A, Ariel E (2009) Susceptibility of pike Esox lucius to a panel of Ranavirus isolates. Dis Aquat Org 83:169-179

Bigarré L, Cabon J, Baud M, Pozet F, Castric J (2008) Ranaviruses associated with high mortalities in catfish in France. Eur Assoc Fish Pathol Bull 28:163-168

Bovo G, Comuzi M, DeMas S, Ceschia G, Giorgetti G, Giacometti P, Cappellozza E (1993) Isolamento di un agente virale irido-like da pesce gatto (Ictalurus melas) dallevamento. Boll Soc Ital Patol Ittica 11:3-10

Boyle DG, Boyle DB, Olsen V, Morgan JAT, Hyatt AD (2004) Rapid quantitative detection of chytridiomycosis (Batrachochytrium dendrobatidis) in amphibian samples using real-time Taqman PCR assay. Dis Aquat Org 60: 141-148

> Brunner JL, Richards K, Collins JP (2005) Dose and host characteristics influence virulence of ranavirus infections. Oecologia 144:399-406

Carey C, Cohen N, Rollins-Smith L (1999) Amphibian declines: an immunological perspective. Dev Comp Immunol 23:459-472

Chinchar VG (2002) Ranaviruses (family Iridoviridae): emerging cold-blooded killers. Arch Virol 147:447-470

Chinchar VG, Essbauer S, He JG, Hyatt A, Miyaki T, Seligy V, Williams T (2005) Iridoviridae. In: Fauquet CM, Mayo MA, Maniloff J, Desselberger U, Gall LA (eds) Virus taxonomy: 8th report of the International Committee on the Taxonomy of Viruses. Elsevier, London, p 163-175
Cullen BR, Owens L (2002) Experimental challenge and clinical cases of Bohle irodovirus (BIV) in native Australian anurans. Dis Aquat Org 49:83-92

Cunningham AA, Langton TES, Bennett PM, Lewin JF, Drury SEN, Gough RE, McGregor SK (1996) Pathological and microbiological findings from incidents of unusual mortality of the common frog (Rana temporaria). Philos Trans R Soc Lond B Biol Sci 351:1539-1557

$>$ Do JW, Cha SJ, Kim JS, An EJ and others (2005) Phylogenetic analysis of the major capsid protein gene of iridovirus isolates from cultured flounders Paralichthys olivaceus in Korea. Dis Aquat Org 64:193-200

> Docherty DE, Meteyer CU, Wang J, Mao JH, Case ST, Chinchar VG (2003) Diagnostic and molecular evaluation of three iridovirus-associated salamander mortality events. J Wildl Dis 39:556-566

Drury SEN, Gough RE, Cunningham AA (1995) Isolation of an iridovirus-like agent from common frogs (Rana temporaria). Vet Rec 137:72-73

> Duffus ALJ, Pauli BD, Wozney K, Brunetti CR, Berrill M (2008) Frog virus 3-like infections in aquatic amphibian communities. J Wildl Dis 44:109-120

> Fijan N, Sulimanovic D, Bearzotti M, Muzinic D and others (1983) Some properties of the Epithelioma papulosum cyprini (EPC) cell line from carp Cyprinus carpio. Ann Inst Pasteur Virol 134:207-220

Fijan N, Matasin Z, Petrinec Z, Valpotic I, Zillenberg LO (1991) Isolation of an iridovirus-like agent from the green frog (Rana esculenta L.). Vet Arh 61:151-158

Fog K, Schmedes A, Rosenørn de Lasson D (1997) Nordens padder og krybdyr. Gad, Copenhagen

$>$ Fox SF, Greer AL, Torres-Cervantes R, Collins JP (2006) First case of ranavirus-associated morbidity and mortality in natural populations of the South American frog Atelognathus patagonicus. Dis Aquat Org 72:87-92

Gascon C, Collins JP, Moore RD, Church DR, McKay JE, Mendelson JR III (eds) (2007) Amphibian Conservation Action Plan. IUCN/SSC Amphibian Specialist Group, IUCN, Gland and Cambridge

Granoff A, Came PE, Rafferty KA (1965) The isolation and properties of viruses from Rana pipiens: their possible relationship to the renal adenocarcinoma of the leopard frog. Ann NY Acad Sci 126:237-255

Green DE, Converse KA, Schrader AK (2002) Epizootology of sixty-four amphibian morbidity and mortality events in the USA, 1996-2001. Ann NY Acad Sci 969:323-339

Greer AL, Berrill M, Wilson PJ (2005) Five amphibian mortality events associated with ranavirus infection in south central Ontario, Canada. Dis Aquat Org 67:9-14

Harp EM, Petranka JW (2006) Ranavirus in wood frogs (Rana sylvatica): potential sources of transmission within and between ponds. J Wildl Dis 42:307-318

Holopainen R, Ohlemeyer S, Schütze H, Bergmann SM, Tapiovaara H (2009) Ranavirus phylogeny and differentiation based on major capsid protein, DNA polymerase and neurofilament triplet H1-like protein genes. Dis Aquat Org (in press)

Hyatt AD, Gould AR, Zupanovic Z, Cunningham AA and others (2000) Comparative studies of piscine and amphibian iridoviruses. Arch Virol 145:301-331

Hyatt AD, Boyle DG, Olsen V, Boyle DB and others (2007) Diagnostic assays and sampling protocols for the detection of $\mathrm{Ba}$ trachochytrium dendrobatidis. Dis Aquat Org 73:175-192

> Jancovich JK, Davidson EW, Morado JF, Jacobs BL, Collins JP (1997) Isolation of a lethal virus from the endangered tiger salamander Ambystoma tigrinum stebbinsi. Dis Aquat Org 31:161-167 
Jancovich JK, Davidson EW, Parameswaran N, Mao J and others (2005) Evidence for emergence of an amphibian iridoviral disease because of human-enhanced spread. Mol Ecol 14:213-224

Jensen NJ, Bloch B, Larsen JL (1979) The ulcus syndrome in cod (Gadus morhua). III. A preliminary virological report. Nord Vet Med 31:436-442

Jørgensen PEV, Olesen NJ, Ahne W, Lorenzen N (1989) SVCV and PFR viruses: serological examination of 22 isolates indicates close relationship between the two fish rhabdoviruses. In: Ahne W, Kurstak E (eds) Viruses of lower vertebrates. Springer-Verlag, Berlin, p 349-366

Kanchanakhan S, Saduakdee U, Kreethachat A, Chinabut S (2002) Isolation of FV3-like iridovirus from a cutaneous ulceration disease of cultured frog, Rana tigrina Cantor, in Thailand. In: Lavilla-Pitogo CR, Cruz-Lacierda ER (eds) Diseases in Asian aquaculture IV. Fish Health Section, Asian Fisheries Society, Manila, p 417-425

Langdon JS (1989) Experimental transmission and pathogenicity of epizootic haematopoietic necrosis virus (EHNV) in redfin perch, Perca fluviatilis L., and 11 other teleosts. J Fish Dis 12:295-310

Langdon JS, Humphrey JD, Williams LM, Hyatt AD, Westbury HA (1986) First virus isolation from Australian fish: an iridovirus-like pathogen from redfin perch, Perca fluviatilis L. J Fish Dis 9:263-268

- Mao J, Green DE, Fellers G, Chinchar VG (1999) Molecular characterisation of iridoviruses isolated from sympatric amphibians and fish. Virus Res 63:45-52

- Marsh IB, Whittington RJ, O'Rourke B, Hyatt AD, Chisholm O (2002) Rapid differentiation of Australian, European and American ranaviruses based on variation in major capsid protein gene sequence. Mol Cell Probes 16: $137-151$

Mendelson JR III, Lips KR, Gagliardo RW, Rabb GB and others (2006) Confronting amphibian declines and extinctions. Science 313:48

Moody NJG, Owens L (1994) Experimental demonstration of the pathogenicity of a frog virus, Bohle iridovirus, for a fish species, barramundi Lates calcarifer. Dis Aquat Org 18:95-102

Editorial responsibility: Alex Hyatt, Geelong, Victoria, Australia
OIE (World Organisation for Animal Health) (2008) Aquatic animal health code. Section 2.4. Diseases of amphibians. OIE, Paris, available at www.oie.int/eng/normes/fcode/ en_titre_2.4.htm

Pearman PB, Garner TWJ, Straub M, Greber UF (2004) Response of the Italian agile frog (Rana latastei) to a Ranavirus, frog virus 3: a model for viral emergence in naïve populations. J Wildl Dis 40:660-669

Rafferty KA Jr (1965) The cultivation of inclusion-associated viruses from Lucké tumor frogs. Ann NY Acad Sci 126: $3-21$

Reed LJ, Muench H (1938) A simple method of estimating fifty percent endpoints. Am J Hygiene 27:493-497

Rojas S, Richards K, Jancovich JK, Davidson EW (2005) Influence of temperature on Ranavirus infection in larval salamanders Ambystoma tigrinum. Dis Aquat Org 63:95-100

Speare R, Smith JR (1992) An iridovirus-like agent isolated from the ornate burrowing frog Limnodynastes ornatus in northern Australia. Dis Aquat Org 14:51-57

Tapiovaara H, Olesen NJ, Lindén J, Rimaila-Pärnänen E, von Bonsdorff CH (1998) Isolation of an iridovirus from pikeperch Stizostedion lucioperca. Dis Aquat Org 32:185-193

Thompson JD, Gibson TJ, Plewniak F, Jeanmougin F, Higgins DG (1997) The CLUSTAL_X windows interface: flexible strategies for multible sequence alignment aided by quality analysis tools. Nucleic Acids Res 25:4876-4882

Weng SP, He JG, Wang XH, Lu L, Deng M, Chan SM (2002) Outbreaks of an iridovirus disease in cultured tiger frog, Rana tigrina rugulosa, in southern China. J Fish Dis 25: 423-427

Williams T, Barbosa-Solomieu V, Chinchar VG (2005) A decade of advances in iridovirus research. Adv Virol 53:905-912

Zhang QY, Xiao F, Li ZQ, Gui JF, Mao J, Chinchar VG (2001) Characterization of an iridovirus from the cultured pig frog Rana grylio with lethal syndrome. Dis Aquat Org 48:27-36

Zupanovic Z, Musso C, Lopez G, Louriero CL, Hyatt AD, Hengstberger S, Robinson AJ (1998) Isolation and characterization of iridoviruses from the giant toad Bufo marinus in Venezuela. Dis Aquat Org 33:1-9

Submitted: December 18, 2008; Accepted: March 17, 2009 Proofs received from author(s): May 7, 2009 